\title{
Dose-dependent in vitro inhibition of rabbit corneal matrix metalloproteinases by an extract of Pothomorphe umbellata after alkali injury
}

L.F.M. Barros ${ }^{1}$, P.S.M. Barros ${ }^{1}$, C.D. Röpke ${ }^{2}$, V.V. Silva' ${ }^{2}$, T.C.H. Sawada², S.B.M. Barros ${ }^{2}$ and R. Belfort Jr. ${ }^{3}$

\author{
${ }^{1}$ Laboratório de Investigação em Oftalmologia Comparada, Departamento de Cirurgia, \\ Faculdade de Medicina Veterinária e Zootecnia, \\ ${ }^{2}$ Departamento de Análises Clínicas e Toxicológicas, \\ Faculdade de Ciências Farmacêuticas, Universidade de São Paulo, São Paulo, \\ SP, Brasil \\ ${ }^{3}$ Instituto da Visão, Universidade Federal de São Paulo, São Paulo, SP, Brasil
}

\footnotetext{
Correspondence

L.F.M. Barros

Av. Prof. Orlando Marques de Paiva, 87 05508-900 São Paulo, SP Brasil

Fax: +55-11-3091-7735

E-mail: Ifbarros@usp.br
}

Presented in abstract form at the ARVO Annual Meeting, Fort Lauderdale, FL, USA. April 30-May 5, 2006.

Research supported by CAPES (MSc fellowship to L.F.M. Barros), CNPq and FAPESP (R. Belfort Jr.).

Received July 1, 2006 Accepted February 26, 2007

\begin{abstract}
The in vitro ability of Pothomorphe umbellata ethanolic crude extract to inhibit matrix metalloproteinase (MMP) in normal cornea and in cornea after alkali injury was demonstrated. Corneas of albino rabbits were injured with $1 \mathrm{~N} \mathrm{NaOH}$ for $20 \mathrm{~s}$. After $48 \mathrm{~h}$ the corneas were excised, homogenized and analyzed for MMP-9 $(92 \mathrm{kDa})$, pro-MMP$2(72 \mathrm{kDa})$ and MMP-2 (67 kDa) activity by gelatin zymography. The activity was also measured in untreated corneas. After electrophoresis of $20 \mu \mathrm{g}$ protein, gels were incubated with 50,100 , or $250 \mu \mathrm{g} / \mathrm{mL}$ lyophilized hydroethanolic (1:1) root crude extract of $P$. umbellata standardized for 4-nerolidylcatechol (7.09\%). The activity of the enzymes was compared with that of untreated gel. At $48 \mathrm{~h}$ after injury, the activity of all MMPs was increased compared with untreated eyes. When the gels were incubated with $P$. umbellata extract the activity of MMP-2, pro-MMP-2 and MMP-9 decreased in a dose-dependent manner. MMP-9 activity decreased by approximately $50 \%$ after incubation with $50 \mu \mathrm{g} / \mathrm{mL}$ and was completely abolished at 100 and 250 $\mu \mathrm{g} / \mathrm{mL}$ of the extract. After incubation with $50 \mu \mathrm{g} / \mathrm{mL}$ the activity of pro-MMP- 2 and MMP- 2 also decreased by $50 \%$. The activity of proMMP-2 was almost completely abolished after incubation with 250 $\mu \mathrm{g} / \mathrm{mL}$ of the extract. For MMP-2 the incubation with 100 or $250 \mu \mathrm{g} /$ $\mathrm{mL}$ of the extract of $P$. umbellata promoted a 10-fold decrease in activity. In conclusion, $P$. umbellata root crude extract can be useful as an alternative therapy to control MMP activity after corneal injury.
\end{abstract}

Key words

- Cornea

- Alkali injury

- Metalloproteinases

- Pothomorphe umbellata
A common complication that follows alkali burn to the eye is cornea damage with impairment of vision. The response is dependent on the severity of the inflammatory cell migration and the release of proteolytic enzymes from these cells (1). Among these enzymes, matrix metalloproteinases (MMPs) are $\mathrm{Zn}$ - and Ca-dependent enzymes responsible for extracellular matrix degradation (2). Failure of cornea re-epithelization is related 
to an increase in MMP activity (3). Treatment of alkali-burned corneas with MMP inhibitors improves basement membrane integrity (4) and promotes corneal wound healing with decreased inflammation (5). Thus, therapeutic strategies that modulate corneal MMP expression may prevent and/or arrest the stromal ulceration that often follows inflammation-mediated injury (6).

Pothomorphe umbellata L. Miq. ("pariparoba"), a plant of the pepper family Piperaceae, is widely used in Brazilian folk medicine for the treatment of liver diseases and healing of skin wounds. The crude ethanolic root extract of this plant is able to inhibit skin MMP-2 and MMP-9 in vitro and to modulate in vivo the extracellular matrix alterations that follow UVB exposure by inhibiting constitutive MMP-9 activity (7). The objective of the present study was to evaluate the in vitro capacity of $P$. umbellata crude extract to inhibit cornea MMPs after alkali injury.

The study was conducted on 4 New Zealand rabbits (one untreated animal and three submitted to corneal injury). Corneal injury was induced in both eyes under general anesthesia by intramuscular injection of $10 \mathrm{mg} / \mathrm{kg}$ ketamine and $2 \mathrm{mg} / \mathrm{kg}$ xylazine with a 5-mm diameter Whatman 42 filter paper soaked in $1 \mathrm{~N} \mathrm{NaOH}$ for $20 \mathrm{~s}$. Normal corneas were included to evaluate the basal activity of MMPs. After $48 \mathrm{~h}$ the animals were euthanized with an overdose of sodium thiopental and both corneas excised under the microscope. Each individual cornea was homogenized on ice at 20,000 rpm for $20 \mathrm{~s}$ in $50 \mathrm{mM}$ Tris- $\mathrm{HCl}$ buffer, $\mathrm{pH}$ 7.4, containing $0.2 \mathrm{M} \mathrm{NaCl}, 5 \mathrm{mM} \mathrm{CaCl}_{2}$, and $0.1 \%$ Triton $\mathrm{X}-100$, using an Ultra-Turax blender (Marconi, Campinas, SP, Brazil). The homogenate was centrifuged at $8000 \mathrm{~g}$ at $4^{\circ} \mathrm{C}$ for 20 min. Zymography was performed with the supernatant in a gel containing $10 \%$ acrylamide and $0.03 \%$ bisacrylamide copolymerized with $0.5 \%$ gelatin. Electrophoresis was performed at $100 \mathrm{~V}$ for $1.5 \mathrm{~h}$. After electro- phoresis $(20 \mu \mathrm{g}$ protein) gels were incubated with 50,100 , or $250 \mu \mathrm{g} / \mathrm{mL}$ freeze-dried ethanol:water (1:1) root crude extract of $P$. umbellata. The gel was stained at room temperature for $30 \mathrm{~min}$ in a $0.5 \%$ solution of Coomassie brilliant blue R-250 containing 25\% methanol and 10\% acetic acid and destained with $10 \%$ acetic acid in water. Gelatinase activity in the cornea extract was detected as unstained zones of degraded gelatin. Each MMP band was quantified densitometrically by computer imaging analysis with a GS-700 densitometer and molecular analysis software, version 1.4 (Bio-Rad, Hercules, CA, USA) (7). P. umbellata crude extract was prepared as previously described (8). Briefly, plant material of $P$. umbellata was obtained from the medicinal herb garden of the Faculdade de Ciências Farmacêuticas, Universidade de São Paulo, and a sample was deposited in the Herbarium of the Instituto de Biociências, Universidade de São Paulo (Silva/Ropke 01) and identified by Prof. José Rubens Pirani (Institute of Biology, University of São Paulo). The roots were dried and ground to a powder. A 100$\mathrm{mL} / \mathrm{g}$ ampunt of the powder was extracted by percolation with ethanol:water (1:1). The recovered filtrate was freeze-dried. The final concentration of 4-NC, a catechol derivative, in the crude extract was $7.09 \%$ (w/ $w$ ), as evaluated by HPLC with electrochemical detection (8).

Experiments were conducted according to the ARVO statement for the use of laboratory animals in Ophthalmic and Vision Research (9).

The data in Figures 1 and 2 indicate a dose-related inhibition of MMPs. MMP-9 activity decreased by approximately 50\% after incubation with $50 \mu \mathrm{g} / \mathrm{mL}$ and was completely abolished with 100 and $250 \mu \mathrm{g} /$ $\mathrm{mL}$ of the extract. After incubation with 50 $\mu \mathrm{g} / \mathrm{mL}$ the activity of pro-MMP-2 and MMP2 also decreased by approximately $50 \%$. The activity of pro-MMP- 2 was almost completely abolished after incubation with 250 
$\mu \mathrm{g} / \mathrm{mL}$ of the extract. For MMP-2 the incubation with 100 or $250 \mu \mathrm{g} / \mathrm{mL}$ of ethanolic root crude extract of $P$. umbellata promoted a 10 -fold decrease in activity.

Many substances have been shown to inhibit gelatinase activity, such as ethylenediaminetetraacetic acid (EDTA), doxycycline, $\mathrm{N}$-acetylcysteine, and autoserum. In vivo only EDTA was able to appreciably inhibit gelatinase activity present on normal canine corneal surface (10). This activity is attributed to chelation of $\mathrm{Zn}$, a metal required for MMP activity, by EDTA. A major component of $P$. umbellata root extract, 4$\mathrm{NC}$, exhibits potent antioxidant activity (11) and is also able to inhibit skin MMP-2 and MMP-9 in vitro (7). Grimm et al. (12) determined the effects of maritime pine bark extract and its two major metabolites on the activity of MMPs. These metabolites (catechols) with a structure closely similar to that of the active compound in P. umbellata, 4-NC, interact directly with the active site of MMP-9, irreversibly inhibiting the enzyme. Green tea (Camellia sinensis) extract and epigallocatechin-3-gallate, a polyphenol constituent of green tea, also directly inhibit the expression of MMP-9 and MMP-2 $(13,14)$. Synthetic MMP inhibitors such as Ilomastat are able to suppress the degradation of the epithelial basement membrane of cornea in an experimental alkali-burned model (15). The present results show that, in addition to skin MMP, corneal MMP can also be inhib-

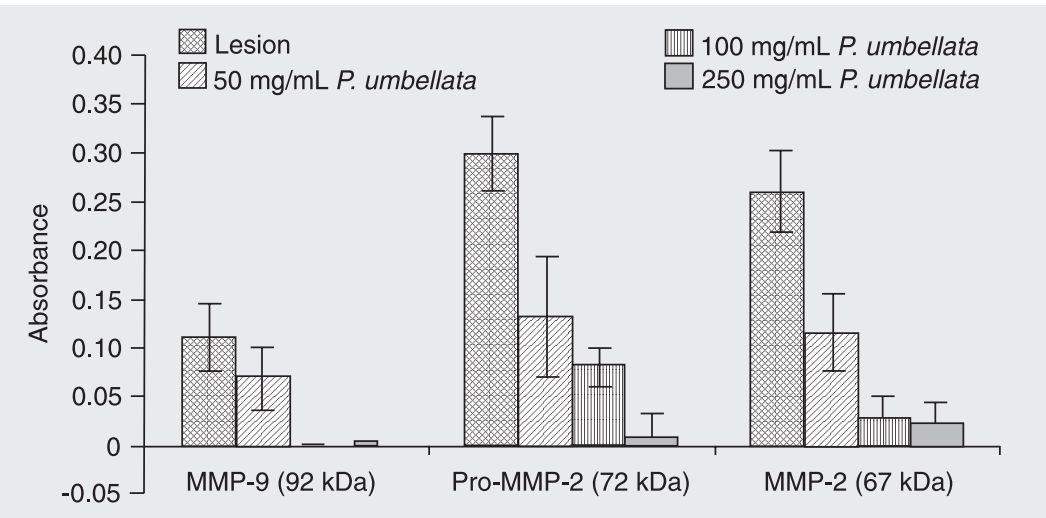

Figure 1. In vitro effect of a crude extract of Pothomorphe umbellata on rabbit corneal metalloproteinase (MMP) activity in alkali-treated eyes. Absorbance of zymograms of cornea homogenates of alkali-treated eyes incubated in the presence or absence of 50 , 100 , or $250 \mu \mathrm{g} / \mathrm{mL} P$. umbellata crude ethanolic root extract. The height of the bars indicate the intensity of the bands obtained from gelatin zymography by densitometry. Data are reported as the mean \pm SD for six independent experiments.

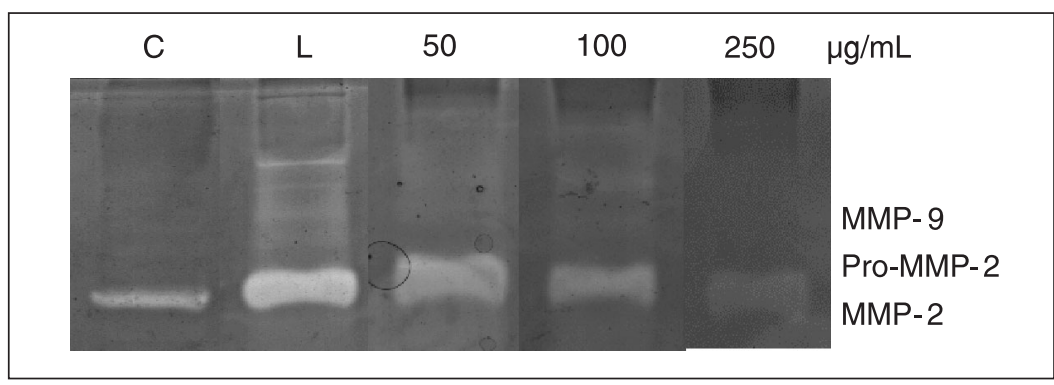

Figure 2. Zymogram of corneal homogenate incubated with increasing concentrations $(\mu \mathrm{g} /$ $\mathrm{mL}$ ) of Pothomorphe umbellata extract. $\mathrm{C}=$ untreated cornea; $\mathrm{L}=$ alkali-treated cornea; MMP = metalloproteinase.

ited by $P$. umbellata extract, suggesting that this plant may be a candidate for the therapy of alkali-burned cornea.

\section{References}

1. Pfister RR, Haddox JL, Dodson RW, Harkins LE. Alkali-burned collagen produces a locomotory and metabolic stimulant to neutrophils. Invest Ophthalmol Vis Sci 1987; 28: 295-304.

2. Nelson AR, Fingleton B, Rothenberg ML, Matrisian LM. Matrix metalloproteinases: biologic activity and clinical implications. $J$ Clin Oncol 2000; 18: 1135-1149.

3. Fini ME, Parks WC, Rinehart WB, Girard MT, Matsubara M, Cook $\mathrm{JR}$, et al. Role of matrix metalloproteinases in failure to re-epithelialize after corneal injury. Am J Pathol 1996; 149: 1287-1302.

4. Pfister RR, Haddox JL, Sommers Cl. Effect of synthetic metallopro- teinase inhibitor or citrate on neutrophil chemotaxis and the respiratory burst. Invest Ophthalmol Vis Sci 1997; 38: 1340-1349.

5. Sosne G, Szliter EA, Barrett R, Kernacki KA, Kleinman H, Hazlett LD. Thymosin beta 4 promotes corneal wound healing and decreases inflammation in vivo following alkali injury. Exp Eye Res 2002; 74: 293-299.

6. Sosne G, Christopherson PL, Barrett RP, Fridman R. Thymosinbeta 4 modulates corneal matrix metalloproteinase levels and polymorphonuclear cell infiltration after alkali injury. Invest Ophthalmol Vis Sci 2005; 46: 2388-2395. 
7. Ropke CD, da Silva V, Kera CZ, Miranda DV, de Almeida RL, Sawada TC, et al. In vitro and in vivo inhibition of skin matrix metalloproteinases by Pothomorphe umbellata root extract. Photochem Photobiol 2006; 82: 439-442.

8. Ropke CD, Kaneko TM, Rodrigues RM, da Silva V, Barros S, Sawada TC, et al. Evaluation of percutaneous absorption of 4nerolidylcathecol from four topical formulations. Int J Pharm 2002 ; 249: 109-116.

9. Association for Research in Vision and Ophthalmology. Statement for the use of animals in ophthalmic and visual research. http:// www.arvo.org/AboutArvo/animals.asp. Accessed June 30, 2003.

10. Couture S, Doucet M, Moreau M, Carrier M. Topical effect of various agents on gelatinase activity in the tear film of normal dogs. Vet Ophthalmol 2006; 9: 157-164.

11. Barros SBM, Teixeira DS, Aznar AE, Moreira JA Jr, Ishii I, Freitas PCD. Antioxidant activity of ethanolic extracts of Pothomorphe umbellata L. Miq. Cienc Cult 1996; 48: 114-116.

12. Grimm T, Schafer A, Hogger P. Antioxidant activity and inhibition of matrix metalloproteinases by metabolites of maritime pine bark extract (pycnogenol). Free Radic Biol Med 2004; 36: 811-822.

13. Vayalil PK, Mittal A, Hara Y, Elmets CA, Katiyar SK. Green tea polyphenols prevent ultraviolet light-induced oxidative damage and matrix metalloproteinases expression in mouse skin. J Invest Dermatol 2004; 122: 1480-1487.

14. Dell'Aica I, Dona M, Sartor L, Pezzato E, Garbisa S. (-)Epigallocatechin-3-gallate directly inhibits MT1-MMP activity, leading to accumulation of nonactivated MMP-2 at the cell surface. Lab Invest 2002; 82: 1685-1693.

15. Kato T, Saika S, Ohnishi Y. Effects of the matrix metalloproteinase inhibitor GM6001 on the destruction and alteration of epithelial basement membrane during the healing of post-alkali burn in rabbit cornea. Jpn J Ophthalmol 2006; 50: 90-95. 